\title{
Effects of Cooking Methods on Sensory, Chemical, and Microbial Characteristics of Broccoli (Brassica
}

\section{Oleracea)}

\author{
Tangkham W. \\ College of Agricultural Sciences \\ McNeese State University of Lake Charles, LA 70609, USA
}

Received: November 20, 2019 Accepted: November 26, 2019 Published: November 30, 2019

doi:10.5296/jfi.v3i1.16039

URL: http://dx.doi.org/10.5296/jfi.v3i1.16039

\begin{abstract}
Broccoli (Brassica oleracea) contains high levels of antioxidants, vitamins and anticarcinogenic properties with associated to health-promoting. The objective of this study was to determine the effects of four cooking methods on the sensory, chemical, and microbial characteristics of broccoli. The following cooking methods: 1) control (fresh broccoli), 2) steaming, 3) boiling and 4) baking were replicated three times. Treatments were analyzed for sensory evaluation, $\mathrm{pH}$ value, \% moisture content, water activity (Aw), color ( $\left.\mathrm{L}^{*}, \mathrm{a}^{*}, \mathrm{~b}^{*}\right)$, aerobic plate counts, E. coli and $S$. aureus. Steamed broccoli had the highest score $(\mathrm{P}<0.05)$ of overall rating $(6.45)$ for sensory testing $(n=140)$ and enhanced green color $\left(a^{*}=-11.49\right)$. The initial moisture content of broccoli in this experiment ranged from 79.09 to $91.78 \%$. Baked broccoli obtained the lowest $(\mathrm{P}<0.05)$ moisture content $(79.09 \%)$, pH value $(6.13)$ and aerobic plate counts (1.24 Log CFU/g). No E. coli and S. aureus were found in this study.
\end{abstract}

Keywords: Broccoli, Cooking methods, Sensory characteristic, Microorganisms

\section{Introduction}

Broccoli is classified by the species Brassica oleracea and contains sulfur compounds which contribute to its characteristic smell and many health benefits including anticancer properties (Fenwick et al., 1983; Carlson et al., 1987), high levels of antioxidants (Traka \& Mithen, 2009) and flavonoids (Wu et al., 2019). Most nutritious compounds are best contracted in fresh or raw vegetables (Wachtel-Galor et al., 2008). In general, most vegetables are commonly cooked before being consumed. Previous studies found that the cooking methods cause significant changes in the overall content of nutrients, chlorophylls, flavonoids, overall texture, and sensory characteristic in vegetables (Brewer et al., 1995; Vallejo et al., 2002; Lin \& Chang, 2005; Cieslik et al., 2007; Sikora et al., 2008; Baenas et al., 2019; 
Danowska-Oziewicz et al., 2019; Wu et al., 2019). Specifically, cooking broccoli under oven with overheated steam or hot air with overheated steam decreased the contents of chlorophylls a and b (Danowska-Oziewicz et al., 2019). Previous research (Baenas et al., 2019) reported that glucosinolates and isothiocyanates are unstable when vegetables are cooked. When heat is applied, the tissues in the plants are damaged and glucosinolates are converted to glucose, which makes the biology of the plant unstable which results in loss of nutrients (Wachtel-Galor et al., 2008; Verkerk et al., 2008; Baenas et al., 2019).

Data on the effects of steaming, boiling, and baking on sensory, chemical, and microbial properties of broccoli are still limited. It is noted that different cooking methods could affect nutritional contents and sensory quality of vegetables in different ways. Thus, it is very important to select appropriate cooking methods in order to retain nutrients while still achieving desired textures and flavors of vegetables. The objectives of this experiment were to investigate the effects of steaming, boiling, and baking on sensory, quality, and nutritional values of broccoli when compared to the control treatment (fresh broccoli).

\section{Materials and Methods}

\subsection{Preparation of Broccoli}

Fresh broccolis were purchased from a local market. Samples were cut to $5 \mathrm{~cm}$ long uniform florets with diameter of 3 to $4 \mathrm{~cm}(\sim 5 \mathrm{~g}$ per piece). Broccoli florets were cleaned, and stems were discarded. Broccoli samples (800 g) were randomly assigned to four treatments: 1) control (fresh broccoli), 2) steaming, 3) boiling, and 4) baking. In the control treatment, fresh broccoli was placed in polyethylene Ziploc and stored at $3^{\circ} \mathrm{C}$. For the cooking methods, one liter of distilled water was added to a steamer. Samples were randomly placed in a steamer for $10 \mathrm{~min}$ when boiled water was reached at $100^{\circ} \mathrm{C}$. For boiling method, $2.5 \mathrm{~L}$ of distilled water was added in a pot and brought to a boil at $100^{\circ} \mathrm{C}$. Broccoli samples were added directly into boiling water for $10 \mathrm{~min}$. In baking method, samples were spread evenly on a baking pan and placed in the oven (30 in. $5.0 \mathrm{cu}$. ft. Electric Range Oven) when temperature was reached at $177^{\circ} \mathrm{C}$. All treatments were begun at the same exact time and taken out in 10 minutes. Each treatment was subject to analyze sensory evaluation, $\mathrm{pH}$ value, \% moisture content, water activity (Aw), color ( $\left.\mathrm{L}^{*}, \mathrm{a}^{*}, \mathrm{~b}^{*}\right)$, aerobic plate counts, E. coli and $S$. aureus.

\subsection{Sensory Evaluation}

The sensory analysis was performed by 140 untrained panelists (45 males and 95 females) from McNeese State University. Samples were served in disposable, odor-free, plastic cups, covered with a watch glass and allowed to reach room temperature before serving. Each panelist was given four samples per session, chosen at random. Broccoli samples were identified by 3-character codes. All samples were tested twice in three different sessions. Nine scales of hedonic testing range from "Like extremely" to "Dislike extremely" for each of the listed food qualities ( $9=$ like extremely, $8=$ like very much, $7=$ Like moderately, $6=$ like slightly, 5 = neither like nor dislike, $4=$ dislike slightly, $3=$ dislike moderately, $2=$ dislike very much, $1=$ dislike extremely) was evaluated for acceptability of appearance, color, texture, flavor, taste, and overall liking. Participants also completed an acceptability and purchase 


\section{I Macrothink}

intent questionnaire.

\section{$2.3 \mathrm{pH}$ Test}

All samples were replicated three times and analyzed $\mathrm{pH}$ values with a probe electrode portable meter (Model 2000 VWR Scientific). Results of this study were expressed as the mean and standard error of the mean (SEM). Calibration of the $\mathrm{pH}$ meter was accomplished using $\mathrm{pH} 7$ and $\mathrm{pH} 4$ standardization buffers before use.

\subsection{Moisture Content}

Moisture content was determined following the method of the Association of Official Analytical Chemists (AOAC, 2000). Each $3 \mathrm{~g}$ sample treatment was dried in a hot air oven (Model 26 Precision Thelco) at $102^{\circ} \mathrm{C}$ for $24 \mathrm{~h}$. The total moisture content was determined by dividing the difference between the pre-dry and dry weights by pre-dry weight.

\subsection{Water Activity Analysis}

Water activity was determined by using an Aqualab Pawkit portable water activity meter (Decagon Devices Inc., Pullman, WA., USA). Broccoli samples were chopped in small homogenous pieces. The, samples were filled cover the bottom of the cup to record the data.

\subsection{Color Test}

Color was evaluated on each treatment with three replications by using a Minolta colorimeter (Model CR-10 portable) with an $8 \mathrm{~mm}$ aperture, $10^{\circ}$ observer angle, D65 illuminant source in terms of $L^{*}(100=$ white, $0=$ black $), a^{*}(+40=$ red, $-40=$ green $), b^{*}(+40=$ yellow, $-40=$ blue).

\subsection{Microbial Counts}

The microorganisms were determined following the standards of the Association of Official Analytical Chemists (AOAC, 2000). Buffered peptone water (BPW) was added as a diluent option for serial dilutions. All samples were plated on $3 \mathrm{M}^{\mathrm{TM}}$ Petrifilm to determine the enumeration $(\log \mathrm{CFU} / \mathrm{g})$ of APC, E. coli, and S. aureus. Samples were incubated in a horizontal position, clear side up in stacks of no more than 20 plates at $37^{\circ} \mathrm{C}$ for $24-48 \mathrm{~h}$. Results were obtained by selecting a countable plate (30-300 colonies) and the colonies were counted and reported as $\mathrm{CFU} / \mathrm{g}$.

\subsection{Statistical Analysis}

Proc GLM procedure of SAS (SAS, 2003) was used to evaluate the significance of differences $(\mathrm{p}<0.05)$ of the data. The LSMEANS was used to determine significance among treatments. All data are presented as means with standard deviation (SD) of each treatment.

\section{Results and Discussion}

\subsection{Sensory Analysis}

The panelists of this study were volunteers solicited through advertisements posted in the Agricultural Sciences building on the McNeese State University Campus. The two largest age 


\section{Macrothink}

groups (18-24 and 45-54 years old) accounted for 57.82\% of the total. Female participants (67.86\%) exceeded males (32.14\%). Most of the consumers reported that they do consume broccoli $(93.65 \%)$. In fact, $59.08 \%$ of consumers reported that they consume raw broccoli and they consumed processed broccoli at $74 \%$. However, the number of consumers who consume baked broccoli is lower, with only $15.87 \%$ responding positively. Using the hedonic scale, cooking methods had a significant effect $(\mathrm{P}<0.05)$ on the appearance, color, texture, flavor, and taste of the cooked broccoli based on evaluations by 140 panelists (Table 1). As expected, steamed broccoli had the highest $(\mathrm{P}<0.05)$ scores of overall liking $(6.45)$, texture (6.39), flavor (5.66) and taste (5.58). These results are consistent with those reported by Bongoni et al. (2014) who found that steamed broccoli retains higher in flavor, texture, and nutrients than boiling method.

Table 1. Sensory evaluation in broccoli cooked by different methods

\begin{tabular}{|l|c|c|c|c|c|}
\hline \multirow{2}{*}{ Properties } & \multicolumn{5}{|c|}{ Sensory Testing } \\
\cline { 2 - 6 } & Fresh & Steamed & Boiled & Baked & SEM \\
\hline Appearance & $6.76^{\mathrm{a}}$ & $6.80^{\mathrm{a}}$ & $6.85^{\mathrm{a}}$ & $5.64^{\mathrm{b}}$ & 0.19 \\
\hline Color & $6.59^{\mathrm{a}}$ & $6.73^{\mathrm{a}}$ & $6.77^{\mathrm{a}}$ & $5.71^{\mathrm{b}}$ & 0.19 \\
\hline Texture & $4.80^{\mathrm{a}}$ & $6.39^{\mathrm{b}}$ & $5.60^{\mathrm{c}}$ & $4.34^{\mathrm{a}}$ & 0.20 \\
\hline Flavor & $3.92^{\mathrm{a}}$ & $5.66^{\mathrm{b}}$ & $5.00^{\mathrm{b}}$ & $3.89^{\mathrm{a}}$ & 0.21 \\
\hline Taste & $3.71^{\mathrm{a}}$ & $5.58^{\mathrm{b}}$ & $4.86^{\mathrm{c}}$ & $3.81^{\mathrm{a}}$ & 0.21 \\
\hline Overall liking & $4.89^{\mathrm{a}}$ & $6.45^{\mathrm{b}}$ & $5.52^{\mathrm{c}}$ & $4.42^{\mathrm{a}}$ & 0.95 \\
\hline
\end{tabular}

a,b,c LSMeans with different superscripts within a row is significantly different $(\mathrm{P}<0.05)$.

\subsection{Physicochemical Analyses}

The initial $\mathrm{pH}$ values of each treatment ranged from 6.13 to 6.88 (Table 2). The $\mathrm{pH}$ values were highest in boiling treatment at 6.88. Baked broccoli samples obtained the lowest $\mathrm{pH}$ value at 6.13. Moisture content of broccoli was significantly $(\mathrm{P}<0.05)$ affected by cooking methods (Table 2). The average initial of moisture content of four treatments were 79.09-91.78\%. Boiled broccoli had the highest \% moisture content with $91.78 \%$ while steamed and baked broccoli treatments contained $88.10 \%$ and $79.09 \%$, respectively (Table 2). This causes the unacceptable and discoloration of broccoli during processing and cooking prior to consumption (Mithen et al., 2000; McNaughton \& Marks, 2003; Wu et al., 2019). The water activity values were significantly affected by the cooking treatments $(\mathrm{P}<0.05)$ (Table 2 ). Boiled broccoli had the highest values of water activity at 0.95 . The lowest value of water activity was observed in broccoli after baking at 0.67 . Color is important to consumers buying decision. In this study, there were differences $(\mathrm{P}<0.05)$ observed in $\mathrm{L}^{*}$ (lightness) and $\mathrm{a}^{*}$ (redness) values between treatments (Table 2). Steamed broccoli had enhanced the bright green color $\left(\mathrm{a}^{*}=-11.49\right.$ ). Regarding $\mathrm{b}^{*}$ (yellowness) value, there was no significant difference $(\mathrm{P}>0.05)$ observed between treatments (Table 2$)$. 


\section{Macrothink}

Table 2. $\mathrm{pH}$, moisture content (\%), Aw and color in broccoli cooked by different methods

\begin{tabular}{|l|c|c|c|c|c|c|}
\hline Treatment & $\mathrm{pH}$ & \multirow{2}{*}{$\begin{array}{c}\text { Moisture } \\
\text { content }(\%)\end{array}$} & \multirow{2}{*}{$\begin{array}{c}\text { Water activity } \\
(\text { Aw })\end{array}$} & \multicolumn{3}{|c|}{ Color } \\
\cline { 5 - 7 } & & & & $\mathrm{L}^{*}$ & $\mathrm{a}^{*}$ & $\mathrm{~b}^{*}$ \\
\hline Fresh & $6.70^{\mathrm{a}}$ & $82.12^{\mathrm{a}}$ & $0.89^{\mathrm{a}}$ & $40.52^{\mathrm{a}}$ & $-9.2^{\mathrm{a}}$ & $17.22^{\mathrm{a}}$ \\
\hline Steamed & $6.62^{\mathrm{a}}$ & $88.10^{\mathrm{b}}$ & $0.94^{\mathrm{b}}$ & $25.19^{\mathrm{b}}$ & $-11.49^{\mathrm{b}}$ & $16.11^{\mathrm{a}}$ \\
\hline Boiled & $6.88^{\mathrm{a}}$ & $91.78^{\mathrm{c}}$ & $0.95^{\mathrm{b}}$ & $30.99^{\mathrm{cd}}$ & $-7.56^{\mathrm{a}}$ & $19.51^{\mathrm{a}}$ \\
\hline Baked & $6.13^{\mathrm{b}}$ & $79.09^{\mathrm{a}}$ & $0.67^{\mathrm{c}}$ & $34.45^{\mathrm{d}}$ & $-6.95^{\mathrm{a}}$ & $21.98^{\mathrm{a}}$ \\
\hline SEM & 0.24 & 0.68 & 0.03 & 1.09 & 1.33 & 1.08 \\
\hline
\end{tabular}

${ }^{a, b, c, d}$ LSMeans with different superscripts within a column is significantly different $(\mathrm{P}<0.05)$.

\subsection{Microbial Counts}

In this study, broccoli was assayed for aerobic plate count, E. coli and $S$. aureus. The initial aerobic plate count of broccoli in this experiment ranged from 1.20 to $2.75 \mathrm{log} \mathrm{CFU} / \mathrm{g}$. Boiled broccoli obtained the highest counts of aerobic bacteria (2.75 Log CFU/g). Baked broccoli had the lowest of aerobic plate count at $1.24 \mathrm{Log} \mathrm{CFU} / \mathrm{g}$. This suggested that baked broccoli under the hot air condition at $300^{\circ} \mathrm{F}$ to $425^{\circ} \mathrm{F}$ can inhibit the growth of aerobic plate counts (Yuan et al., 2009). Additionally, there was no E. coli or $S$. aureus detected for all treatments.

Table 3. Microbial count (Log CFU/g) in broccoli cooked by different methods

\begin{tabular}{|c|c|c|c|}
\hline \multicolumn{4}{|c|}{ Microbial Count (Log CFU/g) } \\
\hline Treatment & Aerobic Plate & E. coli & S. aureus \\
\hline Fresh & $1.29^{\mathrm{a}}$ & 0 & 0 \\
\hline Steamed & $2.52^{\mathrm{b}}$ & 0 & 0 \\
\hline Boiled & $2.75^{\mathrm{b}}$ & 0 & 0 \\
\hline Baked & $1.24^{\mathrm{a}}$ & 0 & 0 \\
\hline
\end{tabular}

${ }^{\mathrm{a}, \mathrm{b}}$ LSMeans with different superscripts within a column is significantly different $(\mathrm{P}<0.05)$.

$\mathrm{SEM}=0.25$.

\section{References}

Association of Official Analytical Chemists (AOAC). (2000). Official methods of analysis (17th ed.). Maryland, MD: Gaithersburg.

Baenas, N., Marhuenda, J., García-Viguera, C., Zafrilla, P., \& Moreno, D. A. (2019). Influence of cooking methods on glucosinolates and isothiocyanates content in novel cruciferous foods. Foods, 8(257), 1-9. https://doi.org/10.3390/foods8070257 
Bongoni, R., Verkerk, R., Steenbekkers, B., Dekker, M., \& Stieger, M. (2014). Evaluation of different cooking conditions on broccoli (Brassica oleracea var. italica) to improve the nutritional value and consumer acceptance. Plant Foods for Human Nutrition, 69(3), 228-34. https://doi.org/10.1007/s11130-014-0420-2

Brewer, M. S., Begum, S., \& Bozeman, A. (1995). Microwave and conventional blanching effects on chemical, sensory and color characteristics of frozen broccoli. Journal of Food Quality, 18, 479-493. https://doi.org/10.1111/j.1745-4557.1995.tb00398.x

Carlson, D. G., Daxenbichler, M. E., VanEtten, C. H., Kwolek, W. F., \& Williams, P. H. (1987). Glucosinolates in crucifer vegetables: broccoli, Brussels sprouts, cauliflower, collards, kale, mustard greens, and kohlrabi. Journal of the American Society for Horticultural Science, 112, 173-178. Retrieved from https://pubag.nal.usda.gov/pubag/downloadPDF.xhtml?id=23901\&content=PDF

Cieslik, E., Leszczynska, T., Filipiak-Florkiewicz, A., Sikora, E., \& Pisulewski, P. M. (2007). Effects of some technological processes on glucosinolate contents in cruciferous vegetables. Food Chemistry, 105(3), 976-981. https://doi.org/10.1016/j.foodchem.2007.04.047

Danowska-Oziewicz, M., Narwojsz, A., Draszanowska, A., \& Marat, N. (2019). The effects of cooking method on selected quality traits of broccoli and green asparagus. International Journal of Food Science and Technology, 1-9. https://doi.org/10.1111/ijfs.14269

Fenwick, G. R., Heaney, R. K., \& Mullin, W. J. (1983). Glucosinolates and their breakdown products in food and food plants. CRC Critical Reviews in Food Science and Nutrition, 18, 123-201. https://doi.org/10.1080/10408398209527361

Lin, C. H., \& Chang, C. Y. (2005). Textural change and antioxidant properties of broccoli under different cooking treatments. Food Chemistry, 90(1-2), 9-15. https://doi.org/10.1016/j.foodchem.2004.02.053

McNaughton, S. A., \& Marks, G. C. (2003). Development of a food composition database for the estimation of dietary intakes of glucosinolates, the biologically active constituents of cruciferous vegetables. British Journal of Nutrition, 90, 687-697. https://doi.org/10.1079/BJN2003917

Mithen, R. F., Dekker, M., Verkerk, R., Rabot, S., \& Johnson, I. T. (2000). The nutritional significance, biosynthesis and bioavailability of glucosinolates in human foods. Journal of the Science of Food and Agriculture, 80, 967-84. https://doi.org/10.1002/(SICI)1097-0010(20000515)80:7<967::AID-JSFA597>3.0.CO;2-V

Sikora, E., Cieslik, E., Leszczynska, T., Filipiak-Florkiewicz, A., \& Pisulewski, P. M. (2008). The antioxidant activity of selected cruciferous vegetables subjected to aquathermal processing. Food Chemistry, 107(1), 55-59. https://doi.org/10.1016/j.foodchem.2007.07.023

Statistical Analysis Software (SAS). (2003). SAS User's Guide Version 9.1.3. North Carolina, NC: Cary.

Traka, M., \& Mithen, R. (2009). Glucosinolates, isothiocyanates and human health. 


\section{Macrothink}

Journal of Food Industry

ISSN 1948-545X 2019, Vol. 3, No. 1

Phytochemistry Reviews, 8(1), 269-282. https://doi.org/10.1007/s11101-008-9103-7

Vallejo, F., Tomas-Barberan, F. A., \& Garcia-Viguera, C. (2002). Glucosinolates and vitamin $\mathrm{C}$ content in edible parts of broccoli florets after domestic cooking. European Food Research and Technology, 215(4), 310-316. https://doi.org/10.1007/s00217-002-0560-8

Verkerk, R., Schreiner, M., Krumbein, A., Ciska, E., Holst, B., Rowland, I., ...\& Dekker, M. (2008). Glucosinolates in Brassica vegetables: The influence of the food supply chain on intake, bioavailability and human health. Molecular Nutrition \& Food Research. https://doi.org/10.1002/mnfr.200800065

Wachtel-Galor, S., Wong, K. W., \& Benzie, I. F. F. (2008). The effect of cooking on Brassica $\begin{array}{llll}\text { vegetables. } & \text { Food } & \text { Chemistry, } & \text { 706-710. }\end{array}$ https://doi.org/10.1016/j.foodchem.2008.02.056

Wu, X., Zhao, Y., Haytowitz, D. B., Chen, P., \& Pehrsson, P. R. (2019). Effects of domestic cooking on flavonoids in broccoli and calculation of retention factors. Heliyon, 5, e01310. https://doi.org/10.1016/j.heliyon.2019.e01310

Yuan, G. F., Sun, B., Yuan, J., \& Wang, Q. M. (2009). Effects of different cooking methods on health-promoting compounds of broccoli. Journal of Zhejang University Science B., 10(8), 580-588. https://doi.org/10.1631/jzus.B0920051

\section{Copyright Disclaimer}

Copyright for this article is retained by the author(s), with first publication rights granted to the journal.

This is an open-access article distributed under the terms and conditions of the Creative Commons Attribution license (http://creativecommons.org/licenses/by/4.0/). 